\title{
Procjena histoloških i histokemijskih analiza uzoraka poluopnastog mišića stražnje strane natkoljenice (musculus semimembranosus) janjadi hranjene uz dodatak svježe biomase plemenite pečurke (Agarícus bisporus)
}

\author{
M. Popović, M. Pavić, S. Vuković, D. Mihelić, D. Leiner, S. Čurković, \\ Ž. Cvrtila, G. Kiš, L. Kozačinski, T. Mikuš, S. Milinković Tur, G. Mršić, \\ B. Njari, L. Pajurin*, N. Poljičak Milas, A. Shek-Vugrovečki, M. Šimpraga, \\ B. Špoljarić, S. Vince, K. Vlahović, I. Žura Žaja i D. Špoljarić
}

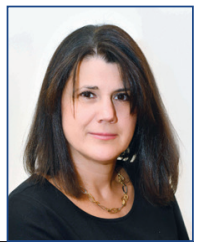

\section{Sažetak}

Plemenita pečurka (Agaricus bisporus), osim što je zdrava hrana, pripada i skupini funkcionalne hrane što potiče daljnja istraživanja njezine primjene kao funkcionalne hrane, odnosno funkcionalnog dodatka hrani ljudima, a i za domaće životinje namijenjene ljudskoj prehrani. Zbog prisutnosti nekih bioaktivnih sastojaka iz skupine polisaharida, lipopolisaharida, esencijalnih aminokiselina, peptida, glikoproteina, nukleozida, triterpenoida, lektina, masnih kiselina i njihovih de-

rivata, za ove gljive poznati su protuupalni, protuvirusni, protubakterijski, hepatoprotektivni, protudijabetički, hipolipemijski, protutrombotski, hipotenzivni učinci i sinbiotska svojstva (neizravni probiotik/izravni prebiotik). U ovom istraživanju opisane su pozitivne naznake smanjenja lipida i povećanja aktivnosti enzima u $m$. semimembranosus janjadi hranjene svježom plemenitom pečurkom, što upućuje na bolji metabolizam i kvalitetu mesa. Na temelju dosadašnjih istraživanja u sklo-

Dr. sc. Maja POPOVIĆ, dr. med. vet., redovita profesorica, Luka PAJURIN*, (Dopisni autor, e-mail: l.pajurin@gmail.com), dr. med. vet. asistent na projektu Hrvatske zaklade za znanost, dr. sc. Daniel ŠPOLJARIĆ, dr. med. vet., docent, dr. sc. Ksenija VLAHOVIĆ, dr. med. vet., redovita profesorica, dr. sc. Mirela PAVIĆ, dr. med. vet., docentica, Snježana VUKOVIĆ, dr. med. vet., redovita profesorica, Damir MIHELIĆ, dr. med. vet., redoviti profesor, Denis LEINER, dr. med. vet., asistent, dr. sc. Snježana ĆURKOVIĆ, dr. med. vet., stručni suradnik, dr. sc. Željka CVRTILA, dipl. ing., redovita profesorica, dr. sc. Lidija KOZAČINSKI, dr. med. vet., redovita profesorica, dr. sc. Tomislav MIKUŠ, dr. med. vet., viši asistent, dr. sc. Bela NJARI, dr. med. vet., redoviti profesor, dr. sc. Suzana MILINKOVIĆ TUR, dr. med. vet., redovita profesorica; dr. sc. Miljenko ŠIMPRAGA, dr. med. vet., redoviti profesor, dr. sc. Ana SHEKVUGROVEČKI, dr. med. vet., docentica, dr. sc. Ivona ŽURA ŽAJA, dr. med. vet., docentica, dr. sc. Nina POLJIČAK MILAS, dr. med. vet., redovita profesorica, dr. sc. Silvijo VINCE, dr. med. vet., izvanredni profesor, dr. sc. Branimira ŠPOLJARIĆ, dr. med. vet., docentica, Veterinarski fakultet Sveučilišta u Zagrebu, Hrvatska; dr. sc. Goran KIŠ, dipl. ing. agr., izvanredni profesor, Agronomski fakultet Sveučilišta u Zagrebu, Hrvatska; dr. sc. Gordan MRŠIĆ, mag. ing. biotechn., naslovni izvanredni profesor, Ministarstvo unutarnjih poslova, Zagreb, Hrvatska 
pu projekta HRZZ-a Inovativni funkcionalni proizvodi od janjećeg mesa (IP-2016-06-3685) te istraživanja prikazanih u ovom radu, može se zaključiti i da $A$. bisporus u janjadi ima potencijalan učinak promotora rasta. Stoga u ovom radu dobiveni rezultati istraživanja imaju znanstveno dokazanu primjenjivu vrijednost za plemenitu pečurku kao prirodan funkcio- nalni dodatak u dnevni obrok za janjad iz kojeg će se predstaviti tržišno novi i inovativni proizvod u obliku funkcionalne hrane za ljude (janjeće meso dobrog aroma profila s obzirom na sastav hlapljivih spojeva podrijetlom iz plemenite pečurke).

Ključne riječi: janjad, plemenita pečurka, musculus semimembranosus

\section{Uvod}

Gljive su od davnina prepoznate kao važna prehrambena namirnica zbog svoje hranjive vrijednosti i ljekovitih svojstava. Tako je zabilježeno da je uzgoj plemenite pečurke (Agaricus bisporus) započeo u Francuskoj još za vrijeme Luja XIV., a prvi znanstveni opis metoda uzgoja datira od 1707. godine (Shek Vugrovečki i sur., 2018.). Danas je upravo plemenita pečurka, odnosno Agaricus bisporus iz koljena Basidiomycetes, jedna od najčešće uzgajanih gljiva u kontroliranim uvjetima $u$ svijetu $i$ to ne samo zbog ugodna okusa i arome nego i zbog svojih nutritivnih i ljekovitih svojstava (Golak-Siwulska i sur., 2018.). Plemenita pečurka bogat je izvor proteina, vlakana (hitina), esencijalnih i poluesencijalnih aminokiselina te antioksidativnih tvari (steroli, fenolni, indolni spojevi, ergotionin, vitamini, selen) (FoulongneOrio i sur., 2013.). Uz to, plemenita pečurka sadržava nizak udio masti u okviru kojih je veći udio mononezasićenih i polinezasićenih u odnosu na zasićene masne kiseline (Öztürk i sur., 2011.). Sve to plemenitu pečurku čini vrlo prihvatljivom zdravom hranom te stoga i vrlo zanimljivom za daljnja istraživanja njezine primjene kao funkcionalne hrane, odnosno funkcionalnog dodatka hrani za ljude, a i za domaće životinje namijenjene ljudskoj prehrani.

Štoviše, zbog prisutnosti nekih bioaktivnih sastojaka, kao što su polisaharidi, lipopolisaharidi, esencijalne aminokiseline, peptidi, glikoproteini, nukleozidi, triterpenoidi, lektini, masne kiseline i njihovi derivati, za ove su gljive poznati protugljivični, protuupalni, protuvirusni, protubakterijski, hepatoprotektivni, protudijabetički, hipolipemijski, protutrombotski, hipotenzivni i sinbiotski učinci (neizravni probiotik/izravni prebiotik) (Atila i sur., 2017., Ferrão i sur., 2019.). Navedene in vivo aktivnosti plemenite pečurke pretežito su u znanstvenoj literaturi opisane kao hrana za ljude i na modelu laboratorijskih životinja. Tako je ustvrđen i njezin imunomodulacijski učinak, odnosno stimulacijski učinak na aktivaciju NK-stanica, na sazrijevanje i funkciju dendritičnih stanica, na pojačano izlučivanje citokina TNF $\alpha$, IFN- $\gamma$ i IL-2, na proizvodnju IgA, odnosno na pomicanje imunosnog odgovora u smjeru imunosti posredovane stanicama (Th-1 imunosnog odgovora) (Atila i sur., 2017., Khan i sur., 2019.). Opisani imunostimulacijski učinak $A$. bisporus posredovan je biokativnim $\beta-1,3-/ 1,6$-glukanom i proteoglikanom koji su ligandi za CD11b/18 (komplementarni receptor 3, CR3), dektin-1 i receptor 2 sličan tollu (TLR2) na monocitima, dendritičnim stanicama (DC), granulocitima i NK-stanicama urođenog imunosnog sustava (Hetland i sur., 2011., Ayeka, 2018.). Nadalje Ayeka (2018.) opisuje da vezanjem na dektin-1, CR3 i TLR-2 dolazi do aktivacije i transdukcije signala T-limfocita, protein-kinaza aktiviranih mitogenom (MAP kinaze) i nuklearnog čimbenika kapa-Bstanica (NF- $\kappa \mathrm{B}$ ) što dovodi do stvaranja 
i aktiviranja kemokina i stimulacije limfocita, makrofaga i NK-stanica. Ditamo i sur. (2016.) u in vivo istraživanjima na modelu štakora ustvrdili su i imunosupresijski učinak lektina izoliranog iz Agaricus bisporusa, zbog čega izolirani lektin ima potencijalnu terapeutsku primjenu oboljelih od autoimunosnih bolesti. Zanimljiv je i mehanizam djelovanja lektina izdvojenog iz plemenite pečurke (ABLlektin), koji se u in vitro uvjetima veže za specifične receptore na membrani mišjih T-limfocita i potiče aktivnost unutarstanične protein-tirozin-kinaze, enzima koji potom aktivira CD25+ i CD69+ rane aktivacijske biljege T-limfocita (Ho i sur., 2004.).

Nadalje, $\beta$-glukan iz plemenite pečurke uspješno utječe i na sniženje razine glukoze $\mathrm{u}$ serumu i to učinkom na smanjenje probave i apsorpcije komponenata hrane kao što je škrob. Osim opisanog učinka na koncentraciju glukoze u serumu poznat je učinak i lovastatina iz plemenite pečurke na sniženje koncentracije kolesterola $u$ serumu (Kała i sur., 2020.). Protumikrobni se učinak plemenite pečurke pripisuje njezinim polisaharidima, odnosno hitosanu i hitinu, za koje su Öztürk i sur. (2011.) ustvrdili inhibicijski učinak na Micrococcus luteus, Micrococcus flavus, Bacillus subtilis, Bacillus cereus, Candidu albicans i Candidu tropicalis. Mogući zdravstveni i imunosni modulacijski učinci plemenite pečurke istraživani su i na monogastričnim životinjama namijenjenima prehrani ljudi. Tako je u dostupnoj literaturi na modelu domaće svinje i peradi držanih u kontroliranim intenzivnim uvjetima te hranjenih uz dodatak plemenite pečurke zabilježen brži rast, niža konverzija hrane, manje obolijevanja, bolje preživljavanje životinja (proizvodni parametri), porast leukocita, snižene serumske koncentracije kolesterola i glukoze, u obriscima rektuma snižen broj bakterije Escherichia coli i enterobakterija te porast broja Lactobacillus spp. (zdravstveni parametri) (Mršić, 2011., Špoljarić, 2013., Špoljarić i sur., 2015., Khan i sur., 2019.). Nadalje Giannenas i sur. (2010.a) ustvrdili su da pripravak osušene plemenite pečurke povoljno djeluje i na crijevnu histomorfologiju peradi kao i na proizvodne pokazatelje i antioksidativni status njihova mesa (Giannenas i sur., 2010.b).

Mršić (2011.) je opisao da pripravak suhe biomase plemenite pečurke nakon umješavanja u komercijalnu hranu za tov pilića u koncentraciji od $10 \mathrm{~g} / \mathrm{kg}$ pokazuje nutritivan, a u koncentraciji od $20 \mathrm{~g} / \mathrm{kg}$ imunostimulacijski učinak na piliće $\mathrm{u}$ tovu tijekom 38 dana (u perifernoj krvi porast udjela: $\mathrm{CD} 45^{+} \mathrm{CD}^{+}$citolitičkih T-limfocita, $\mathrm{CD} 45^{+} \mathrm{CD} 4^{+}$pomoćničkih T-limfocita, dvostruko pozitivnih $\mathrm{CD} 4{ }^{+} \mathrm{CD} 8^{+} \mathrm{T}$-limfocita, $\mathrm{CD} 45^{+} \mathrm{CD} 21^{+} \mathrm{B}-$ limfocita). Slične rezultate opisao je i Špoljarić (2013.) na modelu odbijene prasadi. Imunostimulacijski učinak plemenite pečurke zabilježili su i Hoseinifara i sur. (2019.) nakon osam tjedana hranjenja šarana. Stoga su na temelju u recentnoj literaturi zabilježene znanstveno utemeljene preporuke za uporabu pripravka plemenite pečurke Agaricus bisporus u hrani kao učinkovite prirodne alternative antibiotskim poticateljima rasta (Cvrtila Fleck i sur., 2015., Špoljarić i sur., 2015., Špiranec i sur., 2016.).

Cilj je ovog istraživanja ispitati učinak plemenite pečurke Agaricus bisporus kao funkcionalnog dodatka $\mathrm{u}$ dnevni obrok janjadi i to praćenjem histoloških i histokemijskih aktivnosti u poluopnastom mišiću stražnje strane natkoljenice ( $m$. semimembranosus) janjadi hranjene uz dodatak svježe biomase plemenite pečurke.

\section{Materijali i metode Životinje}

Ovo istraživanje dio je projekta HRZZ Inovativni funkcionalni proizvodi od 

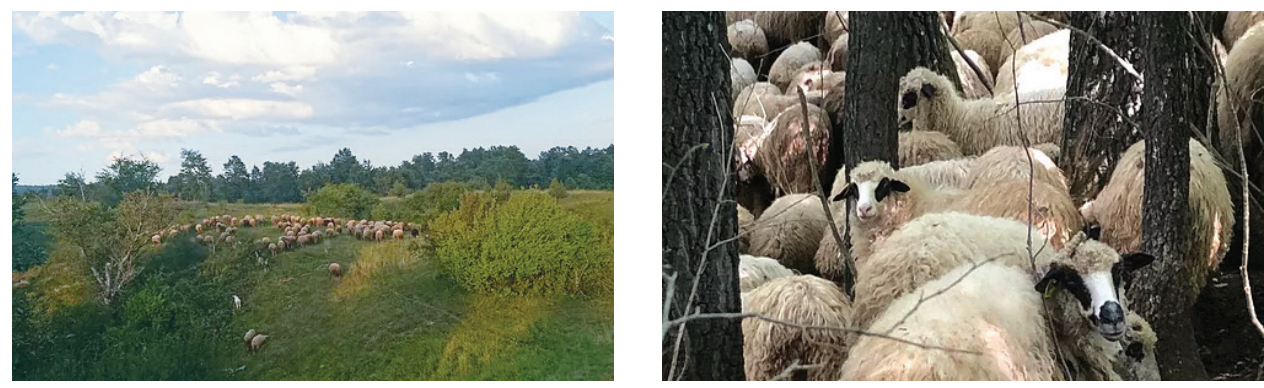

Slika 1. Stado ovaca pasmine lička pramenka (izvor: autori teksta)
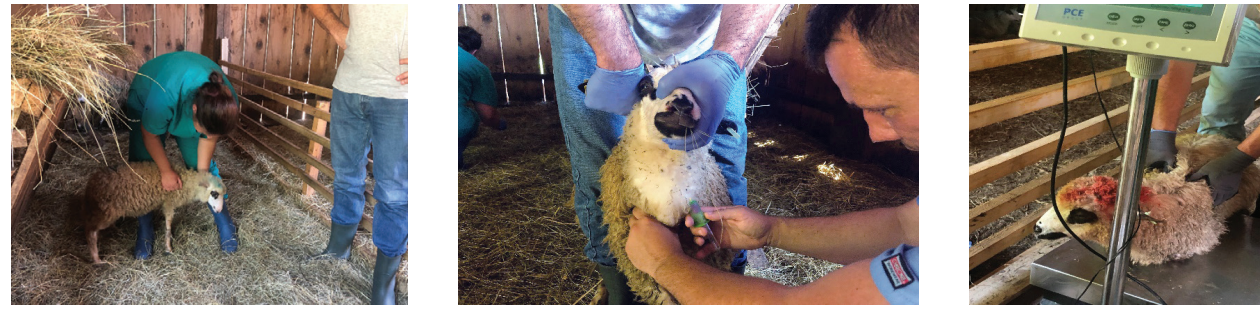

Slika 2. Pokusna janjad pasmine lička pramenka (izvor: autori teksta)

janjećeg mesa (IP-2016-06-3685) za koje je dobivena Odluka Etičkog povjerenstva u veterinarstvu (klasa 640-01/16-17/54; ur. broj 25161-01/139-16-2) Veterinarskog fakulteta Sveučilišta u Zagrebu i Rješenje Ministarstva poljoprivrede R. Hrvatske, Uprave za veterinarstvo i sigurnost hrane Hrvatske (klasa: UP/I-322-01/17-01/31; ur. br.: 525-10/052917-2).

In vivo pokus proveden je od svibnja do srpnja 2019. godine na farmi ovaca (GEA-COM d.o.o., Velika Crkvina, Hrvatska) na ukupno 40 janjadi pasmine lička pramenka $\mathrm{u}$ dobi od tri mjeseca (Slika 1.). Na farmi je smješteno stado od ukupno 200 ovaca, 6 ovnova i većeg broja janjadi. Stado se drži ekstenzivno, $\mathrm{u}$ toplijim mjesecima tijekom godine na ispaši, a zimi u staji. Životinje se u vrijeme pašne sezone drže na ispaši tijekom cijeloga dana, dok se zimi hrane sijenom s okolnih pašnjaka. Četrdeset janjadi odabrane slučajnim izborom bilo je podijeljeno $u$ dvije skupine od kojih je svaka imala 20 životinja (10 ženskog i 10 muškog spola).
Janjadi je procijenjen zdravstveni status prije ulaska $\mathrm{u}$ pokus te su 48 sati prije početka pokusa bili smješteni $u$ pokusne prostore (Slika 2.).

Janjad iz pokusnih skupina držana je odvojeno unutar istog objekta. Tijekom šest tjedana pokusa različito je hranjena, a dnevni obrok sastojao se od voluminoznog dijela i koncentrata (Slika 3.). Voluminozni dio janjad je jela ad libitum, a sastojao se od dnevno košene zelene mase s pašnjaka (područje Velike Crkvine, Hrvatska). Koncentratni dio obroka bila je komercijalna krmna smjesa za janjad sa $16 \%$ sirovih proteina (SP) (Kušić Promet d.o.o.), i to: a) smjesa bez dodatka svježe biomase plemenite pečurke (SBPP) i b) smjesa s dodatkom 1,5\% SBPP-a, koja je bila preformulirana $\mathrm{s}$ umanjenim dijelom SP-a koja se nadoknadila konzumacijom SBPP-a.

Pojedinačne skupine janjadi, prema različitim tretmanima, dobivale su sljedeće kombinacije krmnih smjesa: kontrolna skupina janjadi (skupina K) dobivala je ad libitum dnevno košenu 

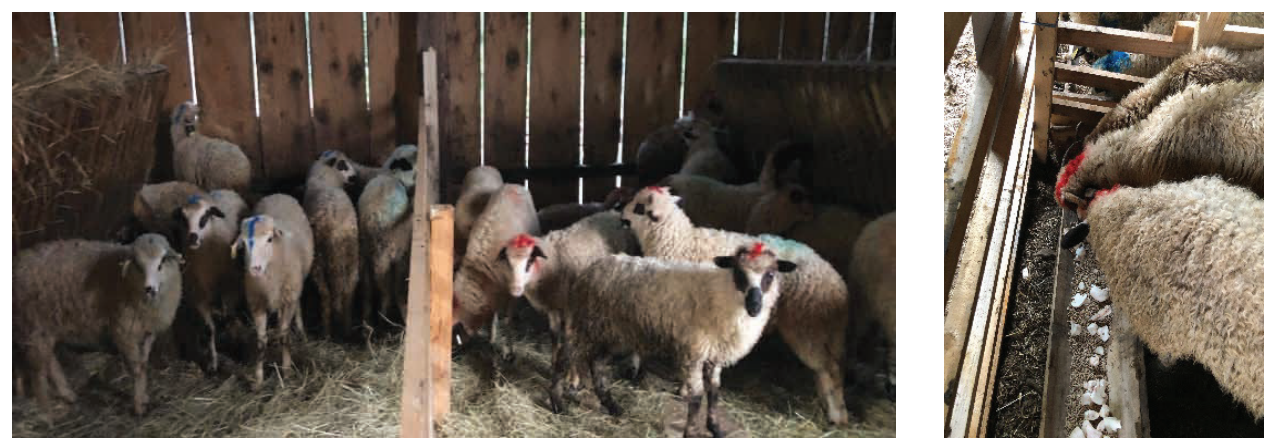

Slika 3. Janjad iz pokusnih skupina pasmine lička pramenka unutar pokusnih prostora lizvor: autori teksta)
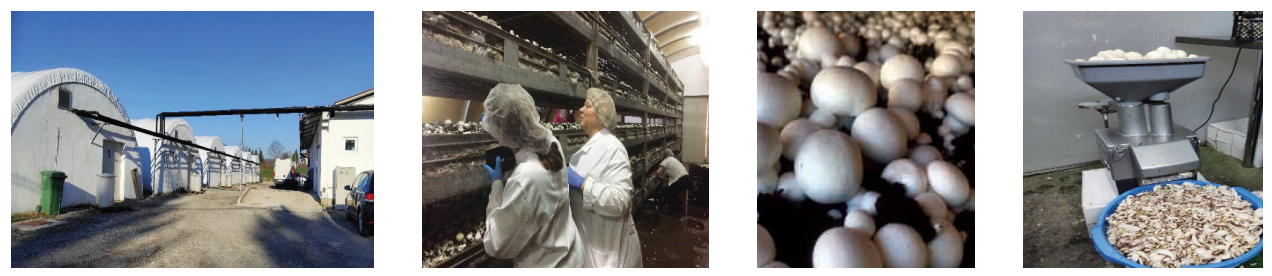

Slika 4. Komercijalni gljivarnik tvrtke GEA-COM d.o.o., Budačka Rijeka, Hrvatska (izvor: autori teksta)
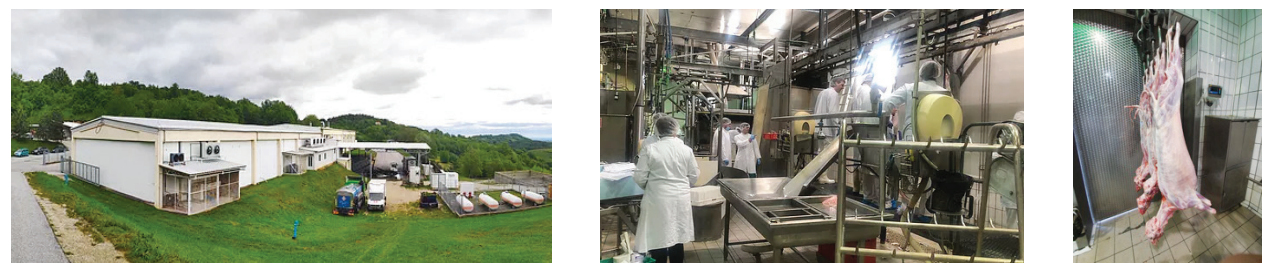

Slika 5. Linija klanja MM mesne industrije d.o.o., Krašić, Gornje Prekrižje (izvor: autori teksta)

zelenu masu i $200 \mathrm{~g}$ krmne smjese; pokusna skupina janjadi (skupina P) dobivala je ad libitum dnevno košenu zelenu masu i $200 \mathrm{~g}$ krmne smjese u čijem je sastavu bilo umiješano $1,5 \%$ svježe biomase bijele plemenite pečurke (SBPP). Svježa biomasa SBPP-a podrijetlom je bila iz odabranog komercijalnog gljivarnika (GEA-COM d.o.o., Budačka Rijeka, Hrvatska) (Slika 4.).

\section{Histološke i histokemijske analize}

Nakon završetka šestotjednog tretmana iz svake skupine od po 10 životinja u klaonici na liniji klanja (MM Mesna indu- strija d.o.o. 10454 Krašić, Gornje Prekrižje 4, Krašić) uzeti su uzorci mišića m. semimembranosus u veličini od $1 \mathrm{do} 2 \mathrm{~cm}^{3}$ te su zamrznuti u tekućem dušiku $\left(-196{ }^{\circ} \mathrm{C}\right)$ i čuvani u ledenici na $-20^{\circ} \mathrm{C}$ do provođenja histoloških i histokemijskih analiza (Slika 5.). Prethodno zamrznuti mišići rezani su serijski na odsječke debljine $6 \mu \mathrm{m}$ kriostatom (Cryotomer, Thermo Shandon) na temperaturi od $-20{ }^{\circ} \mathrm{C}$.

U Laboratoriju za histologiju, histokemiju i imunohistokemiju Zavoda za anatomiju, histologiju i embriologiju Veterinarskog fakulteta Sveučilišta $u$ Zagrebu poprečni rezovi mišićnog tkiva 

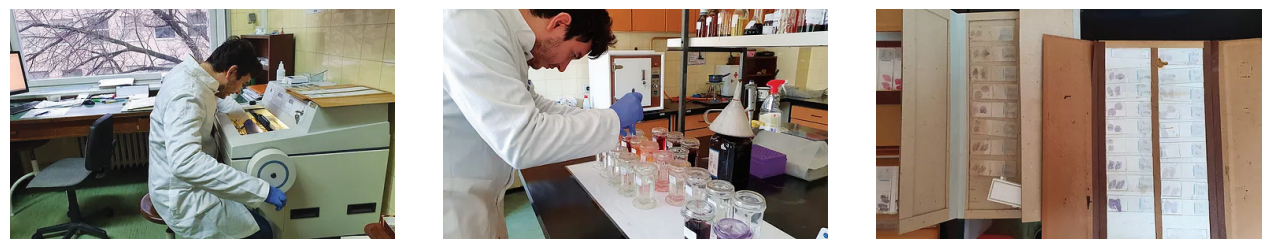

Slika 6. Priprema uzorka za analizu u Laboratoriju za histologiju, histokemiju i imunohistokemiju Zavoda za anatomiju, histologiju i embriologiju Veterinarskog fakulteta Sveučilišta u Zagrebu (izvor: autori tekstal

obojeni su histološkim i histokemijskim metodama (Slika 6.).

Za prikaz mikroskopske građe mišića poprečni rezovi mišićnog tkiva prethodno su fiksirani u $10 \%$-tnom neutralnom formalinu i obojeni rutinskom metodom bojenja hematoksilinom i eozinom (HE). Za prikaz lipida zamrznuti rezovi mišića prethodno su fiksirani u $10 \%$-tnom neutralnom formalinu i obojeni metodom Sudan III (Švob, 1974.). Za prikaz ugljikohidrata korišten je protokol iz komercijalnog kita, Perjodik Acid Schiff, PAS5-100 (Biognost). Weigert Van Gieson (WVG) metoda primijenjena je za bojenje kolagena prema protokolu iz komercijalnog kita WVG-K-100 Weigert Van Gieson (Biognost).

Za procjenu oksidacijske aktivnosti mišićnih vlakana rezovi su obojeni histokemijskim metodama za prikaz lokalizacije aktivnosti sljedećih oksidacijskih enzima: $\quad \alpha$-glicerofosfat-dehidrogenaze $(\alpha-\mathrm{GPDH})$, laktat-dehidrogenaze (LDH/ dehidrogenaza mliječne kiseline), sukcinat-dehidrogenaze (SDH/dehidrogenaza jantarne kiseline) i NADPH-dijaforaza $\left(\mathrm{NADPH}_{2}\right.$ i NADH) prema opisanom protokolu (Pearse, 1972.). Preparati su analizirani svjetlosnim mikroskopom Nikon Microphot-FXA (Nikon Instruments) i kamerom GXCAM-U3-18 (GT Vision Ltd, UK). Za digitalizaciju slika korišten je program GXCapture -T (GT Vision Ltd, UK).

\section{Rezultati i rasprava}

Opasnosti uporabe, ali i zlouporabe antibiotskih poticatelja rasta (APR) u hrani za životinje za ljudsko zdravlje dovele su do zabrane njihove uporabe u Europskoj uniji (Direktiva EK 1831/2003). Naime, od 2006. godine europske upute ograničavaju nekliničku uporabu antibiotskih poticatelja rasta (APR) u proizvodnji životinja namijenjenih ljudskoj prehrani. Stalni zdravstveni problemi u kontroliranom uzgoju životinja uglavnom su se rješavali dodavanjem supterapijskih doza APR-a u hranu zbog preventive/kontrole bolesti i povećanja proizvodnosti. Prilagodba na povlačenje APR-a zahtijeva ustvrđivanje relevantnih zdravstvenih kriterija i donošenje znanstveno utemeljenih alternativnih strategija. Posljedice zabrane APR-a očituju se u slabijoj iskoristivosti hrane i smanjenju proizvodnih svojstava pa tako i u povećanom pobolu i pomoru životinja. Stoga je zaista nužno pronaći alternativno održive metode kontrole stresnih činitelja na zdravlje životinja u odgovarajućim sustavima hranidbe (Špiranec i sur., 2016.) te priključivanje europskim znanstvenim trendovima $u$ veterinarskoj medicini zbog ustvrđivanja relevantnih zdravstvenih kriterija kao i znanstveno utemeljenih preporuka za uporabu APR-a u hrani za životinje (Kozačinski i sur., 2014., Marenčić i sur., 2014.). U suvremenoj proizvodnji domaćih životinja važno je sastaviti recepture koje će poticati rast, a ujedno biti i ekonomski isplative. Takvi obroci, osim što moraju udovoljiti nutritivne potrebe životinja ovisno o vrsti i o uzgojnoj kategoriji, moraju biti djelotvorni u moduliranju selekcije vrsta/sojeva i razvoju 
mikrobiota, stabilizirajući komenzalne mikroorganizme, pospješujući funkciju imunosnog sustava i pojačavajući otpornost na infektivne bolesti.

Današnja istraživanja sve više prepoznaju ulogu nutricina u stvaranju i održavanju dobroga zdravstvenog stanja ljudi i životinja i različitim učincima na metabolizam. Neki od njihovih povoljnih učinaka uključuju: poboljšan unos hrane, smanjenje oksidacijskog stresa, prevenciju rasta mikroorganizama $u$ hrani, modulaciju imunosnog sustava, bolju probavljivost i apsorpciju hranjivih tvari te modifikaciju mikropopulacije probavnog sustava (Pajurin i sur., 2020., Mikuš i sur., 2021., Špoljarić i sur., 2021.). Temeljem u recentnoj literaturi dostupnih spoznaja o pozitivnom učinku plemenite pečurke na modelu monogastričnih životinja, do danas dobiveni rezultati istraživanja na projektu Inovativni funkcionalni proizvodi od janjećeg mesa (IP2016-06-3685) pokazuju da plemenita pečurka dodana u hranu za poligastrične životinje (janjad) ima i pozitivan učinak na zdravlje i proizvodnost janjadi $u$ istraživanju te na parametre ocjene kvalitete i arome sastava njihovog mesa. Naime u našim, do danas neobjavljenim rezultatima, meso janjadi hranjene plemenitom pečurkom sadržava više vakcenske kiseline, omega-7, prekursora konjugirane linolne kiseline (CLA) koji imaju višestruko pozitivne učinke na zdravlje krajnjeg konzumenta (čovjek).

Nadalje Shek Vugrovečki i sur. (2018.) zabilježili su da plemenita pečurka dodana u hranu za janjad pasmine lička pramenka u serumu snižava koncentraciju glukoze i ukupnog kolesterola. Prethodni učinak plemenite pečurke mogao bi se povezati s nalazom povišene koncentracije čimbenika sličnog inzulinu $\mathrm{u}$ serumu koza hranjenih uz dodatak gljiva, za koji je poznato da je funkcionalno uključen $\mathrm{u}$ regulaciju koncentracije glukoze u serumu (Park i sur., 2012.). Na temelju istraživanja Milad i sur. (2001.) o stimulativnom učinku selena na aktivnost glutation-peroksidaze i periferne stanične imunosti $u$ ovaca isti bi se učinak mogao očekivati i tijekom hranjenja janjadi plemenitom pečurkom koja je prirodni izvor selena (Ahlavat i sur., 2016.). Prema istraživanjima Špiranec i sur. (2016.) u četveroglavom bedrenom mišiću (m. quadriceps femoris) zabilježena je povećana aktivnosti oksidacijskih enzima što je rezultiralo pojačanim staničnim metabolizmom i povećanom mišićnom masom jednogodišnjih ovaca hranjenih uz dodatak pripravka plemenite pečurke. U skladu s tim prikazani su rezultati $\mathrm{u}$ ovim istraživanjima na modelu poluopnastog mišića stražnje strane natkoljenice ( $m$. semimembranosus) janjadi hranjene svježom plemenitom pečurkom tijekom šest tjedana.

Naime, histoenzimska aktivnost $\mathrm{u}$ $m$. semimembranosus janjadi hranjene plemenitom pečurkom pokazala je jaču aktivnost oksidacijskih enzima $u$ odnosu na histoenzimsku aktivnost $\mathrm{u}$ $m$. semimembranosus kontrolne janjadi. Isto tako, $\mathrm{u}$ odnosu na kontrolnu janjad zabilježeno je da su dehidrogenaza mliječne i jantarne kiseline bile izraženije $\mathrm{u}$ m. semimembranosus janjadi hranjene plemenitom pečurkom. Navedeno, posebno u slučaju jantarne kiseline, upućuje na pojačanu oksidacijsku aktivnost, odnosno pojačan energetski potencijal u slučaju mliječne kiseline. U odnosu na kontrolnu janjad zabilježena je i nešto slabija aktivnost bojenja za dokazivanje lipida u $\mathrm{m}$. semimembranosus janjadi hranjene plemenitom pečurkom, što može upućivati na mogućnost smanjena deponiranja masnih kiselina $\mathrm{u}$ mišićnom tkivu (Slika 7.).

Sve to, a posebno u slučaju jantarne kiseline, upućujena pojačanu oksidacijsku aktivnost, odnosno pojačan energetski potencijal u slučaju mliječne kiseline. Osim toga, $u$ odnosu na kontrolnu janjad zabilježena je nešto slabija aktivnost bojenja za dokazivanje lipida 


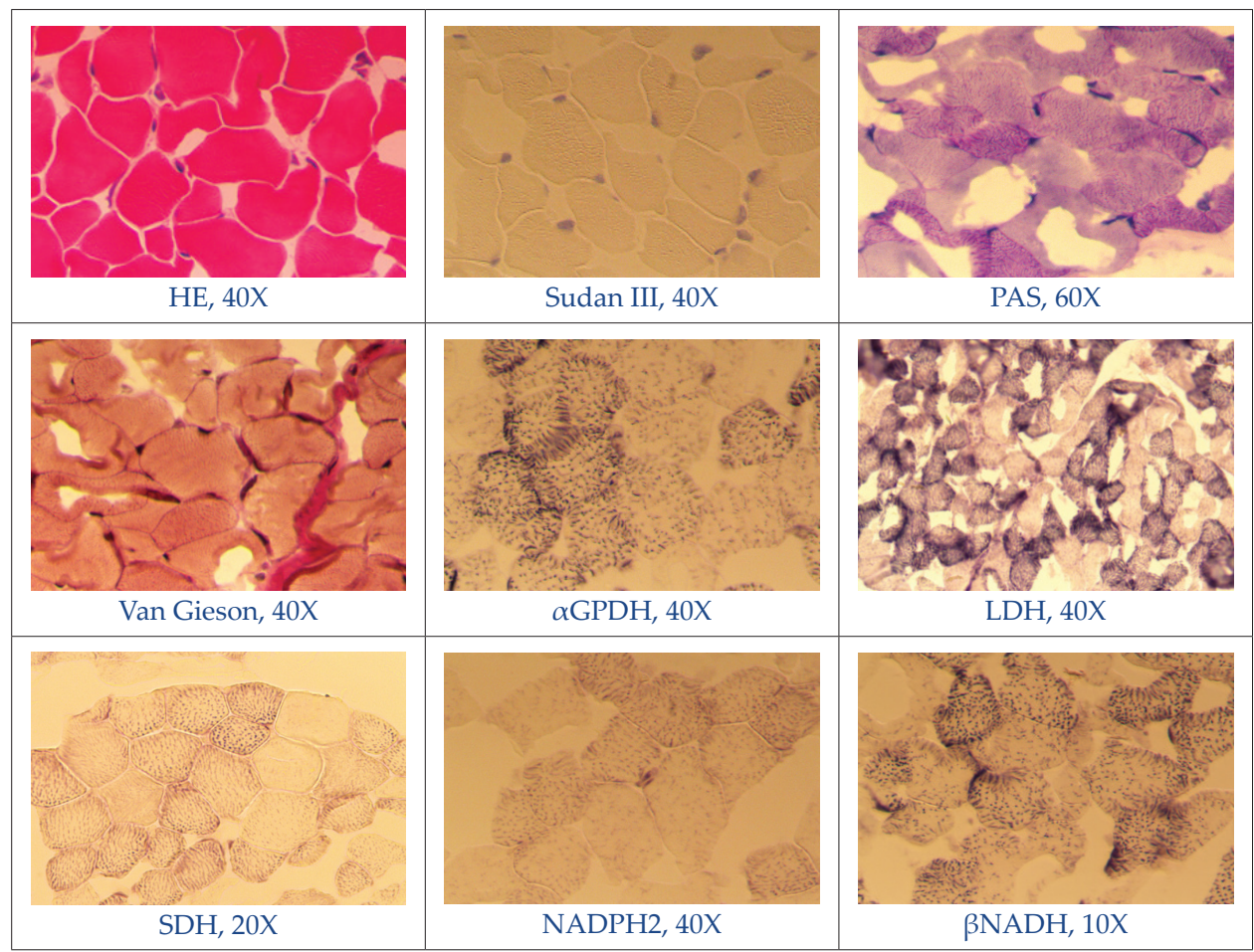

Slika 7. Prikaz histoloških i histokemijskih analiza uzoraka poluopnastog mišića stražnje strane natkoljenice (musculus semimembranosus) janjadi hranjene uz dodatak svježe biomase plemenite pečurke (Agaricus bisporus) (izvor: autori teksta)

u m. semimembranosus janjadi hranjene plemenitom pečurkom, što upućuje na smanjeno deponiranje masnih kiselina $\mathrm{u}$ mišićnom tkivu. Dobiveni rezultati $\mathrm{u}$ skladu su s rezultatima kemijskih analiza mesa istih pokusnih životinja.

Naime, $u$ našim još neobjavljenim rezultatima projekta u uzorcima $m$. semimembranosus podrijetlom od janjadi hranjene svježom biomasom plemenite pečurke utvrđena je statistički niža količina masti u odnosu na kontrolni uzorak. Opisane određene pozitivne naznake smanjenja lipida i povećane aktivnosti enzima u m. semimembranosus janjadi hranjene plemenitom pečurkom upućuju na bolji metabolizam, što bi moglo upućivati i na bolju kvalitetu mesa. Također, na temelju naših dosadašnjih istraživanja na projektu Inovativni funkcionalni proizvodi od janjećeg mesa (IP-2016-06-3685) te istraživanja prikazanih u ovom radu može se zaključiti da Agaricus bisporus u janjadi ima potencijalan učinak promotora rasta. Stoga u ovom radu rezultati istraživanja imaju znanstveno dokazanu primjenjivu vrijednost za plemenitu pečurku kao prirodan funkcionalni dodatak $\mathrm{u}$ dnevni obrok za janjad iz kojeg će se predstaviti tržišno novi i inovativni proizvod u obliku funkcionalne hrane za čovjeka (janjeće meso povoljnog aroma profila s obzirom na sastav hlapljivih spojeva porijeklom iz plemenite pečurke). Ovo istraživanje, kao dio istraživanja projekta HRZZ-a, nudi znanstveno opravdan transfer dobivenih rezultata $\mathrm{u}$ gospodarstvo, odnosno znanstvene preporuke za nova rješenja za uspostavu ujednačenih uzgojnih sustava u ovčarstvu, prihvatljivih za okoliš i za- 
štitnih za zdravlje janjadi u proizvodnji, koji će ujedno biti kompatibilni s propisima EU-a, gospodarski opravdani pa stoga prihvatljivi i za tržišta u zemlji i inozemstvu, i to u javnom (konzumenti), javnozdravstvenom (populacija) i poljoprivrednom sektoru (proizvođači janjetine, plemenite pečurke/stočne hrane).

\section{Zahvala}

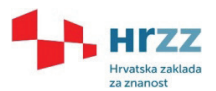

Ovaj je rad financirala Hrvatska zaklada za znanost projektom Inovativni funkcionalni proizvodi od janjećeg mesa (IP-2016-06-3685). Istraživanja su dio EU projekta KK.01.2.1.02.0293.

\section{Literatura}

1. AHLAVAT, O. P., K. MANIKANDAN and M SINGH (2016): Proximate composition of different mushroom varieties and effect of UV light exposure on vitamin D content in Agaricus bisporus and Volvariella volvacea. Mushroom Res. 25, 1-8.

2. ATILA, F., M. N. OWAID and M. A. SHARIATI (2017): The nutritional and medical benefits of Agaricus bisporus: A review. J. Microbiol. Biotech. Food Sci. 7, 281-286.

3. AYEKA, P. A. (2018): Potential of Mushroom Compounds as Immunomodulators in Cancer Immunotherapy: A Review. Evid Based Complement Alternat Med. doi: 10.1155/2018/7271509

4. CVRTILA FLECK, Ž., L. KOZAČINSKI, B. NJARI, D. MARENČIĆ, G. MRŠIĆ, K. ŠPIRANEC, D. ŠPOLJARIĆ, M. J. ČOP, M. ŽIVKOVIĆ and M. POPOVIĆ (2015): Technological properties and chemical composition of the meat of sheep fed with Agaricus bisporus supplement. Vet. arhiv 85, 591-600.

5. DITAMO, Y., L. L. RUPIL, V. G. SENDRA, G. A NORES, G. A. ROTH and F. J. IRAZOQUI (2016): In vivo immunomodulatory effect of the lectin from edible mushroom Agaricus bisporus. Food Funct. 7, 262-269. doi: $10.1039 / \mathrm{c} 5$ fo00360a

6. FERRÃO, J., V. BELL, E. CHAQUISSE, C. GARRINE and T. FERNANDES (2019): The Synbiotic Role of Mushrooms: is Germanium a Bioactive Prebiotic Player? A Review Article. Am. J. Food Nutr. 7, 2635. doi:10.12691/AJFN-7-1-5

7. FOULONGNE-ORIO M., C. MURAT, R. CASTANERA, L. RAMÍREZ and A. D. W. SONNENBERG (2013): Genome-wide survey of repetitive DNA elements in the button mushroom Agaricus bisporus. Fungal Genet. Biol. 55, 6-21.

8. GIANNENAS, I., D. TONTIS and E. ISHAKE (2010a): Influence of dietary mushroom Agaricus bisporus on intestinal morphology and microflora composition in broiler chickens. Res. Vet. Sci. 89, 21-28.

9. GIANNENAS, I., I. S. PAPPAS, S. MAVRIDIS, G. KONTOPIDIS, J. SKOUFOS and I. KYRIAZAKIS (2010b): Performance and antioxidant status of broiler chickens supplemented with dried mushroom (Agaricus bisporus) in their diet. Poult. Sci. 89, 303-311.

10. GOLAK-SIWULSKA, I., A. KAŁUŻEWICZ, S. WDOWIENKO, L. DAWIDOWICZ and $\mathrm{K}$.
SOBIERALSKI (2018): Nutritional value and healthpromoting properties of Agaricus bisporus (Lange) Imbach. Herba Pol 64, 71-81.

11. HETLAND, G., E. JOHNSON, T. LYBERG and G. KVALHEIM (2011): The Mushroom Agaricus blazei and Murill Elicits Medicinal Effects on Tumor, Infection, Allergy, and Inflammation through Its Modulation of Innate Immunity and Amelioration of Th1/Th2 Imbalance and Inflammation. Adv Pharmacol. Sci. doi:10.1155/2011/157015

12. HO, J. C. K., S. C. W. SZE, W. Z. SHEN and W. K. LIU (2004): Mitogenic activity of edible mushroom lectins. Biochim. Biophys. Acta 1671, 9-17.

13. HOSEINIFARA, S. H., H. K. ZOUA, H. PAKNEJADA, A. HAJIMORADLOOA and H. V. DOANB (2019): Effects of dietary white-button mushroom powder on mucosal immunity, antioxidant defence, and growth of common carp (Cyprinus carpio). Aquaculture 501, 448-454.

14. KAŁA, K., A. KRYCZYKPOPRAWA, A. RZEWIŃSKA and B. MUSZYŃSKA (2020): Fruiting bodies of selected edible mushrooms as a potential source of lovastatin. Eur. Food Res. Technol., 246, 713-722.

15. KHAN, S. H., N. MUKHTAR and J. IQBAL (2019): Role of Mushroom as Dietary Supplement on Performance of Poultry. J. Diet. Suppl. 16, 611-624.

16. MARENČIĆ, D., I. PUŠIĆ, L. KOZAČINSKI, B. NJARI, Ž. CVRTILA FLECK and S. MILINKOVIĆ TUR (2014): Utjecaj dodatka selena u hrani i smrzavanja na tehnološka svojstva mesa brojlera. Meso XVI, 151-155.

17. MIKUŠ, T., L. KOZAČINSKI, Ž. CVRTILA, S. VINCE, B. ŠPOLJARIĆ, S. PERKOV, M. M. KARDUM PARO, D. ŠPOLJARIĆ, L. PAJURIN and M. POPOVIĆ (2021): Utjecaj sezone i dobi na razinu lipida, lipoproteina i enzima u serumu ovaca pasmine lička pramenka. Vet. arhiv 91, 31-37.

18. MILAD, K., O. RACZ, A, ŠIPULOVA, V. BAJOVA and G. KOVAČ (2001): Effect of vitamin E and selenium on blood glutathione peroxidase activity and some immunological parameters in sheep. Vet. Med. Czech. 46, 1-5.

19. MRŠIĆ, G. (2011): Nutritivni i imunomodulacijski učinak plemenite pečurke Agaricus bisporus u proizvodnji tovnih pilića. Doktorska disertacija, Veterinarski fakultet, Sveučilište u Zagrebu, Zagreb, Hrvatska.

20. ÖZTÜRK, M., M. E. DURU, S. KIVRAK, N. M. DOGAN, A. TURKOGLU and M. A. OZLER (2011): In vitro antioxidant, anticholinesterase and antimicrobial activity studies on three Agaricus species with fatty acid compositions and iron contents: A comparative study on the three most edible mushrooms. Food Chem. Toxicol. 49, 1353-1360.

21. PAJURIN, L., M. POPOVIĆ, L. KOZAČINSKI, Ž. CVRTILA, G. MRŠIĆ, B. ŠPOLJARIĆ, V. ŠEGOTA, S. VINCE, M. PAVLAK, K. VLAHOVIĆ, G. KIŠ and D. ŠPOLJARIĆ (2020): Procjena brojnosti, gustoće i pokrovnosti majčine dušice (Thymus pulegioides L.) pašnjaka s područja Velike Crkvine. Vet. stn. 51, 507-517.

22. PARK, J. H., S. H. YOON, S. W. KIM, D. SHIN, S. K. JIN, B. S. YANG and Y. M. CHO (2012): Hematological and Serum Biochemical Parameters of Korean Native Goats Fed with Spent Mushroom Substrate. Asian J. Anim. Vet. Adv. 7, 1139-1147.

23. PEARSE, A. G. E. (1972): Histochemistry, Theoretical and Applied. 3 rd ed. 2, Churchill Livingstone. Edinburgh, London. 
24. SHEK-VUGROVEČKI, A. S., M. POPOVIĆ, M. BELIĆ, M. ŽIVKOVIĆ, D. ŠPOLJARIĆ, B. ŠPOLJARIĆ, H. BRZICA, G. MRŠIĆ, Z. FLEGARMEŠTRIĆ, Ž. MIKULEC and M. ŠIMPRAGA (2018): Effect of dietary supplementation with dry and raw white button mushroom (Agaricus bisporus) on biochemical blood parameters of Lika pramenka lambs. Magy. Allatorvosok Lapja 140, 303-312.

25. ŠPIRANEC, K., M. POPOVIĆ, M. ŽIVKOVIĆ, D. ŠPOLJARIĆ, K. VLAHOVIĆ, H. BRZICA, G. MRŠIĆ and D. MIHELIĆ (2016): The metabolic properties of quadriceps femoris muscles of Lika pramenka sheep breed, fed with a supplement from button mushrooms (Agaricus bisporus). Vet. arhiv 86, 541-551.

26. ŠPOLJARIĆ, D. (2013): Modulacijski učinci nativnog propolisa, pripravka plemenite pečurke i $\beta$-glukana na imunosne te proizvodne pokazatelje odbijene prasadi. Doktorska disertacija, Veterinarski fakultet, Zagreb.

27. ŠPOLJARIC, D., S. SREČEC, M. M. KARDUM PARO, M. J. ČOP, G. MRŠIĆ, B. ŠIMPRAGA, M. SOKOLOVIĆ, J. CRNJAC, K. ŠPIRANEC and M. POPOVIĆ (2015): The effects of feed supplemented with Agaricus bisporus on health and performance of fattening broilers. Vet. arhiv 85, 309-322.

28. ŠPOLJARIĆ, D., G. KIŠ, K. VLAHOVIĆ, I. MUJEZINOVIĆ, B. A. HRKOVIĆ POROBIJA, L. PAJURIN, T. MALONE, S. VINCE, V. ŠEGOTA, ŠPOLJARIĆ, M. M. KARDUM PARO and M. POPOVIĆ (2021): Utjecaj botaničkog sastava pašnjaka na imunosni status ovaca pasmine lička pramenka. Vet. stn. 52, 45-55.

29. SVOB, M. (1974): Histološke i histokemijske metode. Svjetlost, Sarajevo, 156.

\section{Histological and histochemical analyses of the posterior thigh muscle (musculus semimembranosus) assessment in lambs fed with the button mushroom (Agaricus bisporus) dietary supplement}

Maja POPOVIĆ, DVM, PhD, Full Professor, Luka PAJURIN, DVM, PhD student, Project Assistant at Croatian Science Foundation, Daniel ŠPOLJARIĆ, DVM, PhD, Assistant Professor, Ksenija VLAHOVIĆ, DVM, PhD, Full Professor, Mirela PAVIĆ, DVM, PhD, Assistant Professor, Snježana VUKOVIĆ, DVM, PhD, Full Professor, Damir MIHELIĆ, DVM, PhD, Full Professor, Denis LEINER, DVM, Assistant, Snježana ĆURKOVIĆ, DVM, PhD, Expert Associate, Željka CVRTILA, BSc, PhD, Full Professor, Lidija KOZAČINSKI, DVM, PhD, Full Professor, Tomislav MIKUŠ, DVM, PhD, Senior Assistant, Bela NJARI, DVM, PhD, Full Professor, Suzana MILINKOVIĆ TUR, DVM, PhD, Full Professor, Miljenko ŠIMPRAGA, DVM, PhD, Full Professor, Ana SHEK-VUGROVEČKI, DVM, PhD, Assistant Professor, Ivona ŽURA ŽAJA, DVM, PhD, Assistant Professor, Nina POLJIČAK MILAS, DVM, PhD, Full Professor, Silvijo VINCE, DVM, $\mathrm{PhD}$, Associate Professor, Branimira ŠPOLJARIĆ, DVM, PhD, Assistant Professor, Faculty of Veterinary Medicine, University of Zagreb, Zagreb, Croatia; Goran KIŠ, BSc, PhD, Associate Professor, Faculty of Agriculture, University of Zagreb, Zagreb, Croatia; Gordan MRŠIĆ, BSc, $\mathrm{PhD}$, Associate Professor, Ministry of the Interior, Zagreb, Croatia

The button mushroom (Agaricus bisporus) is considered both a healthy food and a functional food. This encourages further research into its use as a functional food, or a functional food supplement for both humans and domestic animals intended for human consumption. Due to the presence of several bioactive ingredients, including polysaccharides, lipopolysaccharides, essential amino acids, peptides, glycoproteins, nucleosides, triterpenoids, lectins, fatty acids and their derivatives, these fungi exhibit anti-inflammatory, antiviral, antibacterial, hepatoprotective, antidiabetic, hypolipemic, antithrombotic, hypotensive effects and synbiotic properties (indirect probiotic/direct prebiotic). In this study, positive indications of lipid reduction and increased enzyme activity in m. semimembranosus in lambs fed with fresh button mushroom were described, indicating better metabolism and meat quality. Also, based on previous research within the CSF project "Innovative functional lamb meat products" (IP-2016-06-3685) and the results presented in this paper, it can be concluded that $A$. bisporus in lambs has a potential effect as a growth promoter. Therefore, the research results presented here have a scientifically proven applicable value for the button mushroom as a natural functional dietary supplement in the daily rations for lambs, which will present a commercially new and innovative product in the form of functional human food (lamb meat with a favourable aroma profile based on volatile compounds derived from button mushrooms).

Key words: lambs; button mushroom; musculus semimembranosus 